\title{
Idiopathic CD4 Lymphocytopenia: Spectrum of opportunistic infections, malignancies, and autoimmune diseases
}

\author{
Dina S. Ahmad, Mohammad Esmadi, William C. Steinmann \\ Department of Internal Medicine, University of Missouri School of Medicine, Columbia, MO, USA
}

\begin{tabular}{|c|}
\hline Access this article online \\
\hline Website: www.avicennajmed.com \\
\hline DOI: 10.4103/2231-0770.114121 \\
\hline Quick Response Code: \\
\hline
\end{tabular}

\begin{abstract}
Idiopathic CD4 lymphocytopenia (ICL) was first defined in 1992 by the US Centers for Disease Control and Prevention (CDC) as the repeated presence of a CD4+ T lymphocyte count of fewer than 300 cells per cubic millimeter or of less than $20 \%$ of total T cells with no evidence of human immunodeficiency virus (HIV) infection and no condition that might cause depressed CD4 counts. Most of our knowledge about ICL comes from scattered case reports. The aim of this study was to collect comprehensive data from the previously published cases to understand the characteristics of this rare condition. We searched the PubMed database and Science Direct for case reports since 1989 for Idiopathic CD4 lymphocytopenia cases. We found 258 cases diagnosed with ICL in 143 published papers. We collected data about age, sex, pathogens, site of infections, CD4 count, CD8 count, CD4:CD8 ratio, presence of HIV risk factors, malignancies, autoimmune diseases and whether the patients survived or died. The mean age at diagnosis of first opportunistic infection (or ICL if no opportunistic infection reported) was $40.7 \pm 19.2$ years (standard deviation), with a range of 1 to 85 . One-sixty (62\%) patients were males, $91(35.2 \%)$ were females, and $7(2.7 \%)$ patients were not identified whether males or females. Risk factors for HIV were documented in 36 (13.9\%) patients. The mean initial CD4 count was $142.6 \pm 103.9 / \mathrm{mm}^{3}$ (standard deviation). The mean initial CD8 count was $295 \pm 273.6 / \mathrm{mm}^{3}$ (standard deviation). The mean initial CD4:CD8 ratio was $0.6 \pm 0.7$ (standard deviation). The mean lowest CD4 count was $115.4 \pm 87.1 / \mathrm{mm}^{3}$ (standard deviation). The majority of patients $226(87.6 \%)$ had at least one infection. Cryptococcal infections were the most prevalent infections in ICL patients $(26.6 \%)$, followed by mycobacterial infections (17\%), candidal infections (16.2\%), and VZV infections (13.1\%). Malignancies were reported in $47(18.1 \%)$ patients. Autoimmune diseases were reported in $37(14.2 \%)$ patients.
\end{abstract}

Key words: Autoimmune diseases, idiopathic CD4 lymphocytopenia, Iymphopenia, opportunistic infections

\section{INTRODUCTION}

A 41-year-old female was seen in our Infectious Disease clinic in 2007. She was diagnosed with cutaneous and lymphadenomatous cryptococcal disease in 1995 and subsequently ICL. She has been on only fluconazole $200 \mathrm{mg}$ daily as prophylaxis ever since. She had no recurrence of cryotococcal infections. In 2003, she had an episode of chickenpox and she has been suffering from atopic dermatitis since childhood. Her CD4 count was $64 / \mathrm{mm}^{3}$,
CD8 count $410 / \mathrm{mm}^{3}$, and CD4:CD8 0.15. She remained free of infections on follow up. She did not develop any autoimmune diseases or shingles.

Idiopathic CD4 lymphocytopenia (ICL) was first defined in 1992 by the US Centers for Disease Control and Prevention (CDC) as the repeated presence of a CD4+ T-lymphocyte count of fewer than 300 cells per cubic millimeter or of less than $20 \%$ of total $\mathrm{T}$ cells with no evidence of human immunodeficiency virus (HIV) infection and no condition 
that might cause depressed CD4 counts. Several cases were reported since 1989 with patients having opportunistic infections in the setting of persistent low CD4 counts without HIV infection. This lead the CDC in 1992 to launch a survey in an attempt to characterize this newly evolving entity. The CDC Idiopathic CD4 Lymphocytopenia Task Force reviewed 230,129 cases in the Centers for CDC AIDS Reporting System and found 47 patients to meet the CDC criteria of ICL. Among these 47 patients, $40 \%$ had AIDSdefining illnesses, $53 \%$ had conditions that were not AIDSdefining, and $6 \%$ were asymptomatic. The investigation indicated that ICL is a rare entity with no evidence of transmissible agent since the cases were not clustered and the contacts of the patients had no immunodeficiency. ${ }^{[1]}$

Most of our knowledge about the associated conditions with ICL comes from case reports due to rarity of this condition. A prospective study done by NIH followed 39 ICL patients between 1992 and 2006 to understand the natural history, clinical course, CD4 T lymphocyte kinetics, outcome, and prognostic factors of ICL. Seven patients presented with no infection. Cryptococcal and non-tuberculous mycobacterial infections were the main presenting opportunistic infections. In 32 patients, CD4 T-cell counts remained less than $300 / \mathrm{mm}^{3}$ and in 7 patients normalized after an average of 31 months. Fifteen (41.6\%) developed an opportunistic infection in follow-up, 5 (13.8\%) of which were "AIDS-defining clinical conditions," and 4 (11.1\%) developed autoimmune diseases. Seven patients died, 4 from ICL-related opportunistic infections. ${ }^{[2]}$

The aim of this review was to collect the previously published ICL cases to study its different important aspects. The main studied aspects were age, sex, CD 4 count, CD8 count, CD4:CD8 ratio, presence of HIV risk factors, opportunistic infections, malignancies, autoimmune diseases and whether the patients survived or died.

\section{MATERIALS AND METHODS}

We searched the PubMed database and ScienceDirect for case reports from 1989 to April 2012 using the following keywords: CD4 lymphocytopenia, idiopathic CD4, Idiopathic CD4 lymphocytopenia, ICL, opportunistic infections, Kaposi, TB, mycobacterium, nocardia, PCP, JCV, cryptococcus, CMV, herpes, candida, HPV, and VZV. These were used in various combinations using AND with OR as modifiers. References identified were supplemented with relevant citations from the reference lists of the consulted papers. Only English language papers were reviewed. We found 258 cases diagnosed with ICL in 143 published papers $^{[1,3-145]}$ out of 254 articles found by search. All cases included in this review were diagnosed and published as cases of ICL with negative HIV testing. Negative HIV testing was by ELISA, western blot or PCR. However, we collected only how many patients had negative PCR testing.

We collected data about age, sex, pathogens, site of infections, $\mathrm{CD} 4$ count, $\mathrm{CD} 8$ count, $\mathrm{CD} 4: \mathrm{CD} 8$ ratio, presence of HIV risk factors, malignancies, autoimmune diseases and whether the patients survived or died. Absolute numbers and percentages were calculated. We included our case to the previously published cases. Therefore, the total number of cases became 259. Cases that were present in more than one article were included once in our review.

\section{RESULTS}

The mean age at diagnosis of first opportunistic infection (or ICL if no opportunistic infection reported) was $40.7 \pm 19.2$ years (standard deviation), with a range of 1 to 85 . One patient with ICL was reported to have candidal infections since birth. ${ }^{[43]}$ The oldest patient with ICL was 85 years-old. ${ }^{[22]}$ One-sixty (62\%) patients were males, 91 (35.2\%) were females, and 7 (2.7\%) patients were not identified whether males or females. Four patients had a family member with low CD4 counts. ${ }^{[7,12,51,54]}$ Risk factors for HIV were documented in 36 (13.9\%) patients, while $119(46.1 \%)$ patients had no risk factors. Documentation was lacking for HIV risk factors in 103 (40\%). All patients had some sort of negative HIV test, but PCR was done in 75 (29\%) patients. The rest of the patients, 183 (71\%), had no documentation of whether HIV PCR was done or not. Table 1 shows the general descriptive frequencies of different variables in all ICL patients.

The mean initial CD4 count was $142.6 \pm 103.8 / \mathrm{mm}^{3}$ (standard deviation). The mean initial CD8 count was $295 \pm 273.6 / \mathrm{mm}^{3}$ (standard deviation). The mean initial CD4:CD8 ratio was $0.6 \pm 0.7$ (standard deviation). The mean lowest CD4 count was $115.4 \pm 87.1 / \mathrm{mm}^{3}$ (standard deviation). The mean of the latest reported CD4 count on follow up was $193.2 \pm 155.7 / \mathrm{mm}^{3}$ (standard deviation). CD4 count recovered at some point on follow up to above $300 / \mathrm{mm}^{3}$ in $27(10.4 \%)$ patients. Twenty-four patients died due to their opportunistic infections. Two-hundred patients (77.5\%) survived their presenting illness, whether OI, malignancy, or autoimmune disease. The outcome was not documented in 34 (13.2\%) patients.

The majority of patients, $226(87.6 \%)$, had at least one opportunistic infection. Eighty-five (32.9\%) patients had multiple opportunistic infections. A very few number of infections were detected on autopsies. ${ }^{[23,98]}$ 
Figure 1 shows the most common 10 infections in ICL patients and their percentages. Cryptococcal infections were the most common 69 (26.6\%) in ICL patients. Meningitis was the most common cryptococcal infection followed by pneumonia and then osteomyelitis. Candidal infections were reported in $42(16.2 \%)$ patients. The mouth was the most common site for candidiasis followed by the esophagus.

\begin{tabular}{|c|c|}
\hline \multicolumn{2}{|c|}{$\begin{array}{l}\text { Table I: Frequencies of different variables in all ICL } \\
\text { patients }\end{array}$} \\
\hline Age & $\begin{array}{l}\text { Mean: } 40.7 \text { years } \\
\text { SD: } 19.2\end{array}$ \\
\hline M:F & $\begin{array}{l}\text { Males: I } 60(62) \\
\text { Females: } 9 \text { I (35.2) } \\
\text { Not specified: } 7 \text { (2.7) }\end{array}$ \\
\hline HIV risk factors & $\begin{array}{l}\text { Yes: } 36(13.9) \\
\text { No: } 119 \text { (46.I) } \\
\text { Not specified: } 103 \text { (40) }\end{array}$ \\
\hline HIV PCR & Done: 75 (29) \\
\hline $\begin{array}{l}\text { Patients who had } \\
\text { opportunistic infection(s) }\end{array}$ & $226(87.6)$ \\
\hline Patients who had cancers & 47 (I8.I) \\
\hline $\begin{array}{l}\text { Patients who had } \\
\text { autoimmune disease(s) }\end{array}$ & $37(14.2)$ \\
\hline $\begin{array}{l}\text { Patients who had multiple } \\
\text { opportunistic infections }\end{array}$ & $85(32.9)$ \\
\hline $\begin{array}{l}\text { Patients who had multiple } \\
\text { cancers }\end{array}$ & $15(5.8)$ \\
\hline Outcome & $\begin{array}{l}\text { Died due to OI: } 24 \text { ( } 9.3) \\
\text { Survived at time of diagnosis: } 200 \text { (77.5) } \\
\text { Not specified: } 34 \text { (I3.2) }\end{array}$ \\
\hline Lowest CD4 count & $\begin{array}{l}\text { Mean } 115.4 / \mathrm{mm}^{3} \\
\text { SD } 87.1\end{array}$ \\
\hline Initial CD4 count & $\begin{array}{l}\text { Mean } 142.6 / \mathrm{mm}^{3} \\
\text { SD } 103.8\end{array}$ \\
\hline Initial CD8 count & $\begin{array}{l}\text { Mean } 295 / \mathrm{mm}^{3} \\
\text { SD } 273.6\end{array}$ \\
\hline Initial CD4:CD8 ratio & $\begin{array}{l}\text { Mean } 0.6 / \mathrm{mm}^{3} \\
\text { SD } 0.7\end{array}$ \\
\hline $\begin{array}{l}\text { Latest reported CD4 } \\
\text { count on follow up }\end{array}$ & $\begin{array}{l}\text { Mean } 193.2 / \mathrm{mm}^{3} \\
\text { SD I55.7 }\end{array}$ \\
\hline
\end{tabular}

Twenty (7.7\%) patients had Pneumocystis pneumonia (PCP). Eight patients had infection with histoplasma. Table 2 shows the different fungal infections in ICL patients with the most commonly reported sites of infection.

Varicella zoster virus was the most common viral infection in ICL patients 34 (13.1\%), followed by human papilloma virus 30 (11.6\%), herpes simplex virus $21(8.1 \%)$, and cytomegalovirus 15 (5.8\%). The retina was the most commonly affected site by CMV. Other reported CMV infections included disseminated CMV infections and CMV esophagitis. Table 3 shows the different viral infections in ICL patients. Forty-four (17\%) patients had mycobacterial infections. Mycobacterium tuberculosis was reported in 19 patients. Of these 19 patients, 17 had pneumonia, one patient had colitis, and another patient had UTI. Mycobacterium avium complex was reported in 17 patients. Of these 17 patients, 9 had pneumonia. Table 4 shows the different mycobacterial infections in ICL patients.

\begin{tabular}{lc}
\hline $\begin{array}{l}\text { Table 2: Distribution of fungal infections in ICL patients } \\
\text { (number) }\end{array}$ \\
\hline Fungal infections & Number \\
\hline Candidal infections & 42 \\
Oral & 20 \\
Esophagitis & 10 \\
Pneumonia & 3 \\
Vaginal & 5 \\
Cryptococcus neoformans & 69 \\
Meningitis & 51 \\
Pneumonia & 17 \\
Osteomyelitis & 7 \\
Pneumocystis pneumonia & 20 \\
Histoplasmosis & 8 \\
Aspergillosis & 3 \\
Blastomycosis & 1 \\
Encephalitozoon cuniculi & 1 \\
Exophiala jeanselmei & 1 \\
\hline ICL: Idiopathic CD4 lymphocytopenia &
\end{tabular}

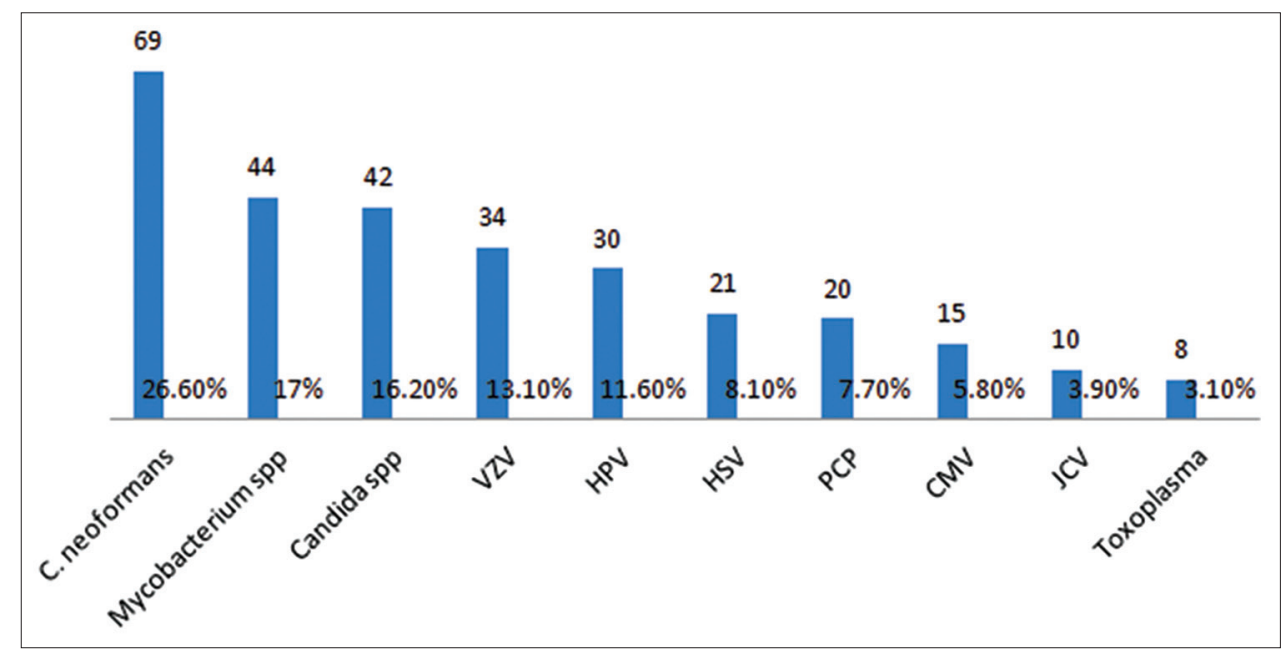

Figure 1: The most common 10 infections in idiopathic CD4 lymphocytopenia patients and their percentages 


\begin{tabular}{lc}
$\begin{array}{l}\text { Table 3: Distribution of viral infections in ICL patients } \\
\text { (number) }\end{array}$ & Number \\
\hline Viral Infection & 34 \\
\hline Varicella zoster virus & 26 \\
Shingles & 4 \\
Disseminated infection & 3 \\
Chickenpox only & 30 \\
Human papilloma virus & 21 \\
Herpes simplex virus I and 2 & 15 \\
Cytomegalovirus & 5 \\
Retinitis & 10 \\
JC virus & 8 \\
Molluscum cotagoiosum & 7 \\
Human herpesvirus 8 & 5 \\
Epstein-Barr virus & 1 \\
Parvovirus B I9 &
\end{tabular}

\begin{tabular}{lc}
\hline Table 4: Distribution of mycobacterial infections in ICL \\
patients (number) & 44 \\
\hline Mycobacterial infections & 19 \\
Mycobacterium tuberculosis & 17 \\
Pneumonia & 2 \\
Disseminated & 17 \\
Mycobacterium avium complex & 9 \\
Pneumonia & 8 \\
Disseminated & 3 \\
Mycobacterium chelonae & 2 \\
Pneumonia & 1 \\
Skin & 1 \\
Mycobacterium kansasii & 1 \\
Pneumonia & 1 \\
Mycobacterium mucogenicum & 1 \\
Disseminated & 1 \\
Mycobacterium xenopi & 1 \\
Pneumonia & 2 \\
Atypical mycobacterium & 2 \\
Not specified & \\
\hline ICL: Idiopathic CD4 lymphocytopenia &
\end{tabular}

Unusual bacterial infections included Nocardia spp, Actinomycosis spp, Fusobacterium nucleatum, and Rhodococcus equi. Protozoal infections were reported in 11 patients. Eight patients had toxoplasmosis. Table 5 shows the different unusual bacterial and protozoal infections reported in ICL patients.

Thirty-seven patients (14.2\%) had autoimmune disease(s). Sjogren's disease was the most common reported autoimmune diseases in ICL patients $(n=8)$, followed by sarcoidosis $(n=7)$, and psoriasis $(n=7)$. Table 6 shows the autoimmune diseases reported in ICL patients. Eczema was reported in five patients, and one patient was reported with allergic rhinitis. Forty-seven (18.1\%) patients had malignancies. Lymphoma with its subtypes, in general, was the most common malignancy in ICL patients. Squamous cell carcinoma of the skin is the second most common malignancy $(n=9)$, followed by

\begin{tabular}{|c|c|}
\hline & Number \\
\hline \multicolumn{2}{|l|}{ Bacterial infections } \\
\hline $\begin{array}{l}\text { Salmonella spp } \\
\text { Enteritis }\end{array}$ & 3 \\
\hline Nocardia spp & 2 \\
\hline Cerebral abscess & 1 \\
\hline Dissemintaed & 1 \\
\hline $\begin{array}{l}\text { Fusobacterium nucleatum } \\
\text { Hepatic abscess }\end{array}$ & 1 \\
\hline Rhodococcus equi & 1 \\
\hline $\begin{array}{l}\text { Actinomycoses spp } \\
\text { Perianal abscess }\end{array}$ & 1 \\
\hline $\begin{array}{l}\text { Corynebacterium jeikeiu } \\
\text { Pneumonia }\end{array}$ & 1 \\
\hline $\begin{array}{l}\text { Shigella spp } \\
\text { Enteritis }\end{array}$ & 1 \\
\hline $\begin{array}{l}\text { Mycoplasma fermentans } \\
\text { Dissemintaed }\end{array}$ & 1 \\
\hline \multicolumn{2}{|l|}{ Protozoal infections } \\
\hline Toxoplasmosis & 8 \\
\hline Cerebral & 7 \\
\hline Disseminated & 1 \\
\hline Cryptosporidiosis & 1 \\
\hline Visceral Leishmaniasis & 1 \\
\hline Giardiasis & 1 \\
\hline
\end{tabular}

\section{Table 6: Distribution of autoimmune diseases in ICL} patients (number)

Autoimmune diseases

Sjogren disease

Number

Sarcoidosis

Psoriasis

Auto immune hemolytic anemia

Idiopathic thrombocytopenic purpura

Systemic lupus erythematosus

Vasculitis

Raynaud's disease

Thrombotic thrombocytopenic purpura

Waldstorm hypergammalobulinemic purpura

Hashimoto thyroiditis

Behçet's-like syndrome

Anti-phospholipid Ab

Alopecia areata

Vitiligo

ICL: Idiopathic CD4 lymphocytopenia

Kaposi's sarcoma $(n=7)$. Table 7 shows the malignancies reported in ICL patients.

\section{DISCUSSION}

Idiopathic CD4 lymphocytopenia is a very rare disease. Cases were reported from all over the world. There is no apparent predilection to one geographical area. Patients are usually diagnosed in the middle of their age. Of the 259 reviewed cases, the mean age was 40.7 years. Most patients were diagnosed upon development of opportunistic 


\begin{tabular}{|c|c|}
\hline \multicolumn{2}{|c|}{$\begin{array}{l}\text { Table 7: Distribution of malignancies in ICL patients } \\
\text { (number) }\end{array}$} \\
\hline Malignancies & Number \\
\hline Squamous cell carcinoma of the skin & 9 \\
\hline Kaposi's sarcoma & 7 \\
\hline Basal cell carcinoma of the skin & 6 \\
\hline Lymphoma (without details on subtype) & 6 \\
\hline Bowen's disease & 6 \\
\hline Non-Hodgkin's lymphoma & 5 \\
\hline Vulvar intraepithelial neoplasia & 3 \\
\hline Primary effusion lymphoma & 2 \\
\hline Mycosis fungoides & 2 \\
\hline Acute lymphoblastic leukemia & 2 \\
\hline Bladder tumor & 2 \\
\hline Cervical intraepithelial neoplasia & 2 \\
\hline Non-small-cell lung carcinoma & I \\
\hline B-cell none-Hodgkin lymphoma & I \\
\hline Large B-cell lymphoma & I \\
\hline Diffuse large B cell lymphoma in bladder then orbit & I \\
\hline Primary leptomeningeal lymphoma & I \\
\hline Gastric cancer & I \\
\hline Prickle cell carcinoma & I \\
\hline Anaplastic astrocytoma & $\mathrm{I}$ \\
\hline Testicular cancer & I \\
\hline Prostate cancer & I \\
\hline Spinocellar carcinoma & I \\
\hline Chronic lymphoblastic leukemia & I \\
\hline
\end{tabular}

infections without the presence of identifiable underlying immunosuppressed status. Few cases were reported within the same family. The male to female ratio was 1.8:1.

ICL patients are susceptible for various opportunistic infections, including AIDS-defining illnesses. The majority of patients $(87.6 \%)$ had at least one infection. Cryptococcal infections were the most prevalent infections in ICL patients (26.6\%), followed by mycobacterial infections (17\%), candidal infections (16.2\%), and VZV infections (13.1\%).

Malignancies were reported in $18.1 \%$ of the patients. Lymphoma with its subtypes, in general, was the most common reported malignancy in ICL patients. Autoimmune diseases were reported in $14.2 \%$ patients. Sjogren's disease was the most common reported autoimmune diseases in ICL patients. Kertava et al. retrospectively studied 115 patients with primary Sjogren's syndrome. Six patients met the criteria of ICL. One patient developed lymphoma in 3 years. They suggested that ICl patients should be screened for primary Sjogren's syndrome. ${ }^{[33]}$

\section{PATHOGENESIS}

ICL is still considered a disorder of unclear etiology. Observational studies suggest factors related to CD4+ lymphocyte function, various immune defects, and genetic elements. An investigation lead by the Centers for Disease Control (CDC) in early 1990's of 47 cases of ICL and their close contacts, sexual partners, children, blood donors, and recipients of the patients' blood did not demonstrate evidence of transmissibility. ${ }^{[1]}$ An extensive search for a viral etiology, utilizing serologic, culture, and PCR testing, was negative. ${ }^{[105]}$ However, Garry et al. demonstrated a cytopathic effect (CPE) of an ICL patient's peripheral blood mononuclear cells (PBMCs) co-cultured with a lymphoblastoid cell line, and identified A-type retroviral particles. ${ }^{[55]}$ In this same study, sera from 8 of 13 ICL patients reacted by Western immunoblotting with these retroviral particles, while control sera remained negative. However, those results were not duplicated in following studies.

Two factors related to CD4+ lymphocyte function play a role in developing ICL. First, increased activation of CD4, which may result from stimulation by an unidentified pathogen, resulting in a persistent decrease in the number of CD4+ lymphocytes. ${ }^{[2]}$ Lee et al. found increased levels of serum lipopolysaccharide (LPS) and markers of CD4+ lymphocyte activation in patients with ICL. Therefore, they hypothesized that abnormally increased microbial translocation through the intestinal wall may be an underlying etiology. ${ }^{[146]}$ Second, apoptosis of CD4+ lymphocyte may be associated with enhanced expression of Fas and Fas ligand. Roger et al. demonstrated that a patient with ICL and disseminated Mycobacterium xenopi infection had over expression of Fas/CD95c and spontaneous and Fas-induced apoptosis. ${ }^{[119]}$ However, patients with stable, physiologic, CD4 cell lymphopenia without opportunistic infections did not demonstrate accelerated apoptosis, suggesting that infection may be a necessary initial stimulus for this phenomenon.

Various other immune defects have been described in some ICL patients as well. Low CD8+ T cells counts were noticed is some patients. Patients with CD 8 counts $<180$ cells $/ \mathrm{mm}^{3}$ in a study of 39 patients were found to have a higher risk of serious opportunistic infections and death. ${ }^{[5]}$ This subgroup of patients may represent a more severe variant of ICL. The complete absence of specific CD8+ cells $(C D 8+28+)$ has been reported in a small number of patients with ICL. ${ }^{[147]}$ Defective expression of CXCR4, which binds the chemokine stromal cell-derived factor 1 , on the surface of CD4+ cells, was noticed in six patients with ICL. ${ }^{[148]}$ The interaction of the receptor/ligand pair is critical for multiple aspects of normal $\mathrm{T}$ cell differentiation and trafficking. The alpha/ beta and gamma/delta T cell repertoires of ICL patients are highly restricted, which may suggest a problem in maturation or differentiation during $\mathrm{T}$ cell development. ${ }^{[68]}$ Biochemical defects of the $\mathrm{T}$ cell receptor transduction pathway have been 
noticed, possibly due to an abnormality of tyrosine kinase activity of p56 (Lck). ${ }^{[13]}$ Defects in this kinase appear to affect $\mathrm{CD} 4$ cell function and maintenance of adequate counts of cells. ICL has been associated with increases in immature or transitional B cells and increased serum levels of IL-7. ${ }^{[149]}$ Low B cell numbers or even a complete absence of B cells has been noticed in some patients. ${ }^{[2,147]}$ Isgrò et al. suggest that ICL may be due to decreased bone marrow clonogenic capability, or the inability of bone marrow stem cells to mature successfully. ${ }^{[56]}$

Genetic factors might be involved in the pathogenesis of ICL as well. Zonios et al. found higher proportions of HLA$\mathrm{DR}+\mathrm{CD} 4$ cells in ICL patients compared to controls, which suggests that there could be a genetic predisposition to ICL, or that ICL is more common in certain populations. ${ }^{[2]}$ Hypomorphic mutations in the recombination activating gene 1 (RAG1) were identified in a patient with Varicella infection and recurrent pneumonias. ${ }^{[58]}$

\section{Non-ICL causes of CD4 Iymphocytopenia}

Various infections, malignancies, and medications can depress the CD4 counts. HIV is the most important cause of CD4 lymphocytopenia. Transient CD4 lymphocytopenia is common and has been estimated to occur in healthy HIV-negative individuals within a $95 \%$ confidence interval from $0.4-4.1 \%$ at any given time. ${ }^{[150]}$ Infections, malignancies, medications and autoimmune diseases can lead to transient CD4 lymphocytopenia. Opportunistic bacterial, ${ }^{[151]}$ viral, parasitic, and fungal diseases may depress CD4 cell counts, but usually without inversion of the CD4:CD8 ratio. ${ }^{[152,153]}$

CD4 lymphocytopenia was found in 9.6\% of HIV-negative hospitalized tuberculosis patients and in $4.2 \%$ of ambulatory tuberculosis patients. ${ }^{[154]}$ Another study showed that CD4 lymphocyte counts below 300 cells $/ \mathrm{ml}$ were found in $14.4 \%$ of HIV-seronegative inpatients with tuberculosis. ${ }^{[96]}$ Lymphocytopenia was noticed to be associated with a more severe course of mycobacterial infections. ${ }^{[96,155]}$ Cytomegalovirus infection can depress CD4 cells and produce a marked increase in CD8 counts, and therefore, an inverted CD4:CD8 ratio. Resolution of cytomegalovirus disease was associated with resolution of those altered counts. ${ }^{[153]}$ Human T-cell lymphotropic virus type II (HTLV-II) is capable of altering CD4 counts for prolonged periods of time in a portion of intravenous drug users and homosexual men. ${ }^{[156]}$

Large cell lymphoma, mucosa-associated lymphatic tissue (MALT) lymphoma, and Burkitt's lymphoma are associated with lymphocytopenia with usually a normal CD4:CD8 ratio. ${ }^{[157]}$ A study evaluated 214 patients with primary Sjögren's syndrome and detected CD4 lymphocytopenia below 300 cells $/ \mathrm{ml}$ in eight patients (3.7\%). ${ }^{[158]}$ In SLE patients, decreased numbers of CD4 $\mathrm{T}$ cells and a low CD4:CD8 ratio were associated with severe renal disease or thrombocytopenia. ${ }^{[159,160]}$ Immunosuppressants such as steroids, cyclophosphamide, azathioprine, and methotrexate might cause CD4 lymphocytopenia. In a study that evaluated CD4 cell counts in patients receiving immunosuppressants, cyclophosphamide produced a more severe depression in lymphocytes and CD4 cells than azathioprine and methotrexate. ${ }^{[161]}$

\section{Prophylaxis and treatment}

Due to the rarity of this condition, no specific guidelines exist for prophylaxis, monitoring, and treatment. Therefore, the management is based on the experience with HIV treatment. Prophylaxis against opportunistic infections is advised using the protocols advocated for HIV-1 infected patients with advanced disease. Monitoring every four months with CD4 counts might be sufficient for stable patients without apparent infections. Once those patients develop signs of infection, they need close attention.

In the prospective study by Zonios et al., the CD4 T-cell counts in their patients remained less than $300 / \mathrm{mm}^{3}$ for several years with absence of progression of lymphocytopenia over time. One-fifth of their patients resolved their lymphocytopenia within 3 years of diagnosis. Therefore, they suggested that it is reasonable to consider following ICL patients more closely during the first 3 years because of the risk of serious infections and the possibility if normalization of CD4 T-cell counts, allowing discontinuation of any prophylaxis if initially given. ${ }^{[2]}$

Zonios et al. in another study followed 11 patients with cryptococcosis and idiopathic CD4 lymphocytopenia (ICL) referred to their institution, as well as 42 similar cases reported in the literature. Different treatment regimens were used in cryptococcal infections. Therefore, one cannot compare the effectiveness of these regimens. The relapse rate of cryptococcal infections in ICL patients is low compared to HIV patients. ICl patients with cryptococcal infections have a favorable outcome in general. ${ }^{[22]}$

A few investigators reported successful treatment with IL-2 for opportunistic infection associated with ICL. The idea of IL-2 came from its use in HIV patients with CD4+ lymphopenia. IL-2 has showed significant increase in $\mathrm{CD} 4$ counts and possible clinical improvement in immunological function. Limited data from those reports support IL-2 as a relatively safe and potentially effective 
treatment for ICL patients with opportunistic infections, especially when combined with conventional treatment regimens. ${ }^{[30,50,72,93,101]}$

\section{Limitations}

Case reports varied in quality and completeness. Although all cases were published as ICL, one can still question the diagnosis, especially in cases with conditions which are known to depress CD4 counts, like mycobacterial infections and malignancies. One example is a case that was diagnosed with aplastic anemia four months after the diagnosis of ICL. That patient underwent a bone marrow (BM) biopsy on presentation and two months after presentation. Both biopsies were negative for malignancy or aplasia. On a third biopsy four months after presentation, aplastic anemia criteria were met. One could very easily argue that aplastic anemia probably existed at the time of presentation since the diagnosis of aplastic anemia was done just four months after and explains the depressed CD4 counts. ${ }^{[131]}$

Relationship between the level of CD4 and CD8 and the opportunistic infections could not be made because many patients had several opportunistic infections, but the counts were recorded around one opportunistic infection only.

\section{ACKNOWLEDGMENT}

Dr. William Salzer from the Department of Infectious Diseases, University of Missouri, for reviewing the paper. Rebecca ChitimaMatsiga, MPH, for conducting the data analysis.

IRB approval was obtained for the brief case presented at the beginning of the review.

\section{REFERENCES}

1. Smith DK, Neal JJ, Holmberg SD. Unexplained opportunistic infections and CD4+ T-lymphocytopenia without HIV infection. An investigation of cases in the United States. The Centers for Disease Control Idiopathic CD4+ T-lymphocytopenia Task Force. N Engl J Med 1993;328:373-9.

2. Zonios DI, Falloon J, Bennett JE, Shaw PA, Chaitt D, Baseler MW, et al. Idiopathic CD4+ lymphocytopenia: Natural history and prognostic factors. Blood 2008;112:287-94.

3. Bohm M, Luger TA, Bonsmann G. Disseminated giant molluscum contagiosum in a patient with idiopathic CD4+ lymphocytopenia. Successful eradication with systemic interferon. Dermatology 2008;217:196-8.

4. Campbell JK, Prince HM, Juneja SK, Seymour JF, Slavin M. Diffuse large cell lymphoma and $\mathrm{t}(8 ; 22)(\mathrm{q} 24 ; \mathrm{q} 11)$ in a patient with idiopathic CD4+ T-lymphopenia. Leuk Lymph 2001;41:421-3.

5. Grossman D, Lewis DE, Ballas ZK, Duvic M. Idiopathic CD4+ $\mathrm{T}$ lymphocytopenia in a patient with mycosis fungoides. J Am Acad Dermatol 1994;31:275-6.

6. Hanamura I, Wakita A, Harada S, Tsuboi K, Komatsu H, Banno S, et al. Idiopathic CD4+ T-lymphocytopenia in a non-Hodgkin's lymphoma patient. Intern Med 1997;36:643-6.
7. Lin SJ, Chao HC, Yan DC, Kuo ML. Idiopathic CD4+ T lymphocytopenia in two siblings. Pediatr Hematol Oncol 2001;18:153-6.

8. Ohashi DK, Crane JS, Spira TJ, Courrege ML. Idiopathic CD4+ T-cell lymphocytopenia with verrucae, basal cell carcinomas, and chronic tinea corporis infection. J Am Acad Dermatol 1994;31:889-91.

9. Paolini R, D'Andrea E, Poletti A, Del Mistro A, Zerbinati P, Girolami A. $B$ non-Hodgkin's lymphoma in a haemophilia patient with idiopathic CD4+ T-lymphocytopenia. Leuk Lymph 1996;21:177-80.

10. Stevens SR, Griffiths TW, Cooper KD. Idiopathic CD4+ $\mathrm{T}$ lymphocytopenia in a patient with mycosis fungoides. J Am Acad Dermatol 1995;32:1063-4.

11. Vertes D, Linden MD, Carey JL. Idiopathic CD4+ T-lymphocytopenia: analysis of a patient with selective IgA deficiency and no evidence of HIV infection. Cytometry 1995;22:40-4.

12. Wakeel RA, Urbaniak SJ, Armstrong SS, Sewell HF, Herriot R, Kernohan N, et al. Idiopathic CD4+ lymphocytopenia associated with chronic pruritic papules. Br J Dermatol 1994;131:371-5.

13. Hubert P, Bergeron F, Ferreira V, Seligmann M, Oksenhendler E, Debre $\mathrm{P}$, et al. Defective p56Lck activity in T cells from an adult patient with idiopathic CD4+ lymphocytopenia. Int Immunol 2000;12:449-57.

14. Juhi T, BibhaBati M, Aradhana B, Poonam L, Vinita D, Archana T. Cryptococcal meningitis in a tertiary care hospital. Nihon Ishinkin Gakkai Zasshi (Jpn J Med Mycol) 2009;50:95-9.

15. Kumlin U, Elmqvist LG, Granlund M, Olsen B, Tarnvik A. CD4 lymphopenia in a patient with cryptococcal osteomyelitis. Scand J Infect Dis 1997;29:205-6.

16. Ramirez JA, Srinath L, Ahkee S, Huang AK, Raff MJ. HIV-negative "AIDS" in Kentucky: A case of idiopathic CD4 + lymphopenia and cryptococcal meningitis. South Med J 1994;87:751-2.

17. Salit RB, Hankey KG, Yi R, Rapoport AP, Mann DL. Detection of CD4(+) T-cell antibodies in a patient with idiopathic CD4 T lymphocytopenia and cryptococcal meningitis. Br J Haematol 2007;139:133-7.

18. Sancesario G, Palmieri G, Viola G, Fontana C, Perfetti A, Anemona L, et al. Difficulty diagnosing chronic cryptococcal meningitis in idiopathic CD4+ lymphocytopenia. Neurol Sci 2011;32:519-24.

19. Scheer M, Rabbels J, Neugebauer J, Cornely OA, Drebber U, Zoeller JE. Combined intra- and extracranial cryptococcal infection of a 20-year-old patient in right temporal area. J Oral Maxillofac Surg 2011;69:222-6.

20. Seligmann M, Aractingi S, Oksenhendler E, Rabian C, Ferchal F, Gonnot G. CD4+ lymphocytopenia without HIV in patient with cryptococcal disease. Lancet 1991;337:57-8.

21. Sharma A, Lal V, Modi M, Khurana D, Bal S, Prabhakar S. Idiopathic CD4 lymphocytopenia presenting as refractory cryptococcal meningitis. Ann Indian Acad Neurol 2010;13:136-8.

22. Zonios DI, Falloon J, Huang CY, Chaitt D, Bennett JE. Cryptococcosis and idiopathic CD4 lymphocytopenia. Medicine 2007;86:78-92.

23. Bordin G, Ballare M, Paglino S, Ravanini P, Dulio D, Malosso MC, et al. Idiopathic CD4+ lymphocytopenia and systemic vasculitis. J Intern Med 1996;240:37-41.

24. Ferrer X, Vital C, Larriviere M, Richard S, Julien J. Idiopathic CD4+ T-cell lymphocytopenia and subacute inflammatory demyelinating polyradiculoneuropathy. Neurology 1995;45:196-7.

25. Goodrich AL, Tigelaar RE, Watsky KL, Heald PW. Idiopathic CD4+ lymphocyte deficiency. Report of an unusual case associated with atopic dermatitis and allergic contact dermatitis and review of the literature. Arch Dermatol 1993;129:876-8.

26. Guma M, Krakauer R. CD4+ lymphocytopenia in systemic lupus erythematosus. Ann Intern Med 1994;120:168-9.

27. Hardman CM, Baker BS, Lortan J, Breuer J, Surentheran T, Powles A, et al. Active psoriasis and profound CD4+ lymphocytopenia. Br J Dermatol 1997;136:930-2.

28. Siderits RH, Ouattara O, Marcus A, Gao HG, Deng HB, Godyn J. Case study documenting the diagnosis of idiopathic CD4+ Lymphocytopenia 
in a patient with atypical fungal infection (disseminated blastomycosis) by FNA of adrenal mass. Cytojournal 2010;7:13.

29. Stasi R, Delpoeta G, Venditti A, Coppetelli U, Masi M, Papa G. Clinical heterogeneity of idiopathic CD4+ T lymphocytopenia. J Intern Med 1994;235:92-3.

30. Wilhelm M, Weissinger F, Kunzmann V, Muller JG, Fahey JL. Idiopathic CD4 $+\mathrm{T}$ cell lymphocytopenia evolving to monoclonal immunoglobulins and progressive renal damage responsive to IL-2 therapy. Clin Immunol 2001;99:298-304.

31. Wladis EJ, Kapila R, Chu DS. Idiopathic CD4+ lymphocytopenia and Sjogren syndrome. Arch Ophthalmol 2005;123:1012.

32. Yamauchi PS, Nguyen NQ, Grimes PE. Idiopathic CD4+T-cell lymphocytopenia associated with vitiligo. J Am Acad Dermatol 2002;46:779-82.

33. Kirtava Z, Blomberg J, Bredberg A, Henriksson G, Jacobsson L, Manthorpe R. CD4+ T-lymphocytopenia without HIV infection: increased prevalence among patients with primary Sjogren's syndrome. Clin Exp Rheumatol 1995;13:609-16.

34. Ahn IS, Kim HG, Ryu JS, Kim L, Kwak SM, Lee HL, et al. A case of pulmonary cryptococcosis with non-small cell lung cancer in idiopathic CD4+ T-lymphocytopenia. Yonsei Med J 2005;46:173-6.

35. Cheung MC, Rachlis AR, Shumak SL. A cryptic cause of cryptococcal meningitis. CMAJ 2003;168:451-2.

36. Gatenby PA. Reduced CD4 $+\mathrm{T}$ cells and candidiasis in absence of HIV infection. Lancet 1989;1:1027-8.

37. Hamanishi T, Nakao T, Nishino M, Yanagawa T, Kobayashi M, Sasaki H, et al. Idiopathic CD4+ T lymphocytopenia disclosed by the onset of empyema thoracis. Intern Med 1999;38:40-4.

38. Hoang QV, Simon DM, Kumar GN, Oh F, Goldstein DA. Recurrent CMV retinitis in a non-HIV patient with drug-resistant CMV. Graefes Arch Clin Exp Ophthalmol 2010;248:737-40.

39. McLane NJ, Weems JJ Jr, Antworth MV. Cytomegalovirus retinitis in a patient with idiopathic CD4+ T lymphocytopenia. Clin Infect Dis 1994;18:1012-3.

40. Pankhurst C, Peakman M. Reduced CD4 $+\mathrm{T}$ cells and severe oral candidiasis in absence of HIV infection. Lancet 1989;1:672.

41. Reichart PA, Pohle HD, Gelderblom HR. Oral manifestations in a patient with idiopathic CD4+ lymphocytopenia. Int J Oral Maxillofac Surg 1996;25:290-2.

42. Sloan DJ, Taegtmeyer M, Pearce IA, Hart IJ, Miller AR, Beeching NJ. Cytomegalovirus retinitis in the absence of HIV or immunosuppression. Eur J Ophthalmol 2008;18:813-5.

43. von Bernuth H, Knochel B, Winkler U, Roesler J, Schlesier M, Gahr M. Immunodeficiency with recurrent panlymphocytopenia, impaired maturation of $B$ lymphocytes, impaired interaction of $T$ and B lymphocytes, and impaired integrity of epithelial tissue: A variant of idiopathic CD4+ T lymphocytopenia? Pediatr Allergy Immunol 2002;13:381-4.

44. Augustine R, Khalid M, Misri ZK, Hegde S. Idiopathic CD4+ T-lymphocytopenia-a diagnostic dilemma. J Assoc Physicians India 2010;58:45-7.

45. Ho CL, Chang BC, Hsu GC, Wu CP. Pulmonary cryptococcoma with CD4 lymphocytopenia and meningitis in an HIV-negative patient. Respirat Med 1998;92:120-2.

46. Kofteridis DP, Saridaki Z, Kazakou I, Lazaridou S, Alegakis D, Milaki G, et al. Idiopathic $\mathrm{CD} 4+\mathrm{T}$ lymphocytopenia disclosed by recurrent cryptococcal meningitis. First case report from Greece. Int J Infect Dis 2005;9:347-8.

47. Lepur D, Vranjican Z, Barsic B, Himbele J, Klinar I. Idiopathic Cd4+T-lymphocytopenia-two unusual patients with cryptococcal meningitis. J Infect 2005;51:E15-8.

48. Menon BS, Shuaib IL, Zamari M, Haq JA, Aiyar S, Noh LM. Idiopathic CD4+ T-lymphocytopenia in a child with disseminated cryptococcosis. Ann Trop Paediatr 1998;18:45-8.
49. Schattner A, Friedman J, Bentwich Z. Opportunistic infection due to unexplained CD4+ lymphocytopenia and associated Sjogren's syndrome. Rheumatology 2004;43:111-2.

50. Yilmaz-Demirdag Y, Wilson B, Lowery-Nordberg M, Bocchini JA Jr, Bahna SL. Interleukin-2 treatment for persistent cryptococcal meningitis in a child with idiopathic CD4(+) T lymphocytopenia. Allergy Asthma Proc 2008;29:421-4.

51. Yinnon AM, Rudensky B, Sagi E, Breuer G, Brautbar C, Polacheck I, et al. Invasive cryptococcosis in a family with epidermodysplasia verruciformis and idiopathic CD4 cell depletion. Clin Infect Dis 1997;25:1252-3.

52. Yuanjie Z, Julin G, Fubing C, Jianghan C. Recurrent pulmonary cryptococcosis in a patient with idiopathic CD4 lymphocytopenia. Med Mycol 2008;46:729-34.

53. Zanelli G, Sansoni A, Ricciardi B, Ciacci C, Cellesi C. Muscular-skeletal cryptococcosis in a patient with idiopathic CD4+ lymphopenia. Mycopathologia 2001;149:137-9.

54. Freier S, Kerem E, Dranitzki Z, Schlesinger M, Rabinowitz R, Brautbar C, et al. Hereditary CD4+ T lymphocytopenia. Arch Dis Childhood 1998;78:371-2.

55. Garry RF, Fermin CD, Kohler PF, Markert ML, Luo H. Antibodies against retroviral proteins and nuclear antigens in a subset of idiopathic CD4+ T lymphocytopenia patients. AIDS Res Hum Retroviruses 1996;12:931-40.

56. Isgro A, Sirianni MC, Gramiccioni C, Mezzaroma I, Fantauzzi A, Aiuti F. Idiopathic CD4+ lymphocytopenia may be due to decreased bone marrow clonogenic capability. Int Arch Allergy Immunol 2005; 136:379-84.

57. Kaiser FE, Morley JE. Idiopathic CD4+ T lymphopenia in older persons. J Am Geriatr Soc 1994;42:1291-4.

58. Kuijpers TW, Ijspeert H, van Leeuwen EM, Jansen MH, Hazenberg MD, Weijer KC, et al. Idiopathic CD4 + T lymphopenia without autoimmunity or granulomatous disease in the slipstream of RAG mutations. Blood 2011;117:5892-6.

59. Laurence J, Mitra D, Steiner M, Lynch DH, Siegal FP, StaianoCoico L. Apoptotic depletion of CD4 + T cells in idiopathic CD4+ T lymphocytopenia. J Clin Investig 1996;97:672-80.

60. Matsuyama W, Mizoguchi A, Hamasaki T, Wakimoto J, Iwami F, Kawabata M, et al. Idiopathic CD4+ T-lymphocytopenia in chronic obstructive pulmonary disease. Int Med 1999;38:71-2.

61. McNulty A, Kaldor JM, McDonald AM, Baumgart K, Cooper DA. Acquired immunodeficiency without evidence of HIV infection: National retrospective survey. BMJ 1994;308:825-6.

62. Netea MG, Brouwer AE, Hoogendoorn EH, Van der Meer JW, Koolen M, Verweij PE, et al. Two patients with cryptococcal meningitis and idiopathic CD4 lymphopenia: defective cytokine production and reversal by recombinant interferon- gamma therapy. Clin Infect Dis 2004;39:e83-7.

63. Rezza G, Pezzotti P, Aiuti F. Acquired immunodeficiency without HIV infection: Epidemiology and clinical outcome in Italy. The Italian Study Group on non-HIV AIDS. BMJ 1995;311:785-6.

64. Alisjahbana B, Dinata R, Sutedja E, Suryahudaya I, Soedjana H, Hidajat NN, et al. Disfiguring generalized verrucosis in an indonesian man with idiopathic CD4 lymphopenia. Arch Dermatol 2010;146:69-73.

65. Duncan RA, von Reyn CF, Alliegro GM, Toossi Z, Sugar AM, Levitz SM. Idiopathic CD4+ T-lymphocytopenia--four patients with opportunistic infections and no evidence of HIV infection. N Engl J Med 1993;328:393-8.

66. Fruhwirth M, Clodi K, Heitger A, Neu N. Lymphocyte diversity in a 9-year-old boy with idiopathic CD4 + T cell lymphocytopenia. Int Arch Allergy Immunol 2001;125:80-5.

67. Hansen ER, Lisby S, Baadsgaard O, Ho VC, de Villiers EM, Vejlsgaard GL. Abnormal function of CD4+ helper/inducer T lymphocytes in a patient with widespread human papillomavirus type 3-related infection. Arch Dermatol 1990;126:1604-8.

68. Signorini S, Pirovano S, Fiorentini S, Stellini R, Bianchi V, Albertini A, 
et al. Restriction of T-cell receptor repertoires in idiopathic CD4+ lymphocytopenia. Br J Haematol 2000;110:434-7.

69. Spira TJ, Jones BM, Nicholson JK, Lal RB, Rowe T, Mawle AC, et al. Idiopathic CD4+ T-lymphocytopenia-an analysis of five patients with unexplained opportunistic infections. N Engl J Med 1993;328:386-92.

70. Stetson CL, Rapini RP, Tyring SK, Kimbrough RC. CD4+ Tlymphocytopenia with disseminated HPV. J Cutan Pathol 2002;29:502-5.

71. Tumbarello M, Tacconelli E, Colosimo C, Cauda R, Ortona L. Meningoencephalomyelitis caused by herpes simplex virus- 1 in a patient with idiopathic T CD4+ lymphocytopenia. Neurology 1998;50:569-70.

72. Warnatz K, Draeger R, Schlesier M, Peter HH. Successful IL-2 therapy for relapsing herpes zoster infection in a patient with idiopathic CD4+ T lymphocytopenia. Immunobiology 2000;202:204-11.

73. Etienne M, Gueit I, Abboud P, Pons JL, Jacquot S, Caron F. Fusobacterium nucleatum hepatic abscess with pylephlebitis associated with idiopathic CD4(+) T lymphocytopenia. Clin Infect Dis 2001;32:326-8.

74. Fischer LA, Norgaard A, Permin H, Ryder LP, Marquart H, Svejgaard A, et al. Multiple flat warts associated with idiopathic CD4-positive T lymphocytopenia. J Am Acad Dermatol 2008;58(2 Suppl):S37-8.

75. Hochauf K, Bandt D, Pohlmann C, Monecke S, Toma M, Trautmann S. Fatal varicella zoster virus infection as first manifestation of idiopathic CD4+ T-cell lymphocytopenia. Eur J Clin Microbiol Infect Dis 2005;24:706-8.

76. Kojima M, Sakurai S, Morita Y, Nakamura N, Sugihara S, Shimano S. EBV $(+)$ B-cell lymphoproliferative disorder associated with subsequent development of Burkitt lymphoma in a patient with idiopathic CD4(+) T-lymphocytopenia. J Clin Exp Hematopathol 2008;48:55-9.

77. Mazzucchelli I, Vezzoli M, Ottini E, Paulli M, Boveri E, Mazzone A. A complex immunodeficiency. Idiopathic CD4+ T-lymphocytopenia and hypogammaglobulinemia associated with HHV8 infection, Kaposi's sarcoma and gastric cancer. Haematologica 1999;84:378-80.

78. Niino D, Tsukasaki K, Torii K, Imanishi D, Tsuchiya T, Onimaru Y, et al. Human herpes virus 8-negative primary effusion lymphoma with BCL6 rearrangement in a patient with idiopathic CD4 positive T-lymphocytopenia. Haematologica 2008;93:e21-3.

79. Park K, Monk BJ, Wilczynski S, Ito JI Jr, Vasilev SA. Idiopathic CD4+ T-lymphocytopenia and recurrent vulvar intraepithelial neoplasia. Obstetr Gynecol 1994;84:712-4.

80. Pasic S, Minic P, Dzudovic S, Minic A, Slavkovic B. Idiopathic CD4+ lymphocytopenia and juvenile laryngeal papillomatosis. Pediatr Pulmonol 2005;39:281-3.

81. Sneller MC, Eisenstein EM, Baseler M, Lane HC, Donoghue ET, Falloon J. A unique syndrome of immunodeficiency and autoimmunity associated with absent T cell CD2 expression. J Clin Immunol 1994;14:359-67.

82. Van Wagoner JA, Khan DA. Selective CD4 $+\mathrm{T}$ cell lymphocytopenia and recalcitrant warts in an 8-year-old child. Ann Allergy Asthma Immunol 2001;87:373-8.

83. Anzalone G, Cei M, Vizzaccaro A, Tramma B, Bisetti AM. Kansasii pulmonary disease in idiopathic CD4+ T-lymphocytopenia. Eur Respir J 1996;9:1754-6.

84. Busse PJ, Cunningham-Rundles C. Primary leptomeningeal lymphoma in a patient with concomitant CD4+ lymphocytopenia. Ann Allergy Asthma Immunol 2002;88:339-42.

85. Cook MA, Bareford D, Kumararatne DS. Non-Hodgkin's lymphoma: An unusual complication of idiopathic CD4+ lymphopenia. Hosp Med 1998;59:582.

86. Cozon G, Greenland T, Revillard JP. Profound CD4+ lymphocytopenia in the absence of HIV infection in a patient with visceral leishmaniasis. N Engl J Med 1990;322:132.

87. Eftekhari K, Say EA, Shields CL, Gausas RE, Shields JA. Orbital lymphoma in the setting of idiopathic CD4+ lymphocytopenia (HIV-negative AIDS). Ophthal Plast Reconstr Surg 2011;27:e134-6.

88. Kodjikian L, Garweg JG, Nguyen M, Schaffner T, Deplazese P, Zimmerli S. Intraocular microsporidiosis due to Encephalitozoon cuniculi in a patient with idiopathic CD4+ T-lymphocytopenia. Int J Med Microbiol 2005;294:529-33.

89. Kortsik C, Elmer A, Tamm I. Pleural effusion due to Histoplasma capsulatum and idiopathic CD4 lymphocytopenia. Respiration 2003;70:118-22.

90. Mongardon N, Bruneel F, Henry-Lagarrigue M, Legriel S, Azarian R, Bedos JP. Pneumonia involving Mycobacterium tuberculosis and Pneumocystis jiroveci in HIV-seronegative patients. Eur J Intern Med 2008;19:e70-2.

91. Nakahira M, Matsumoto S, Mukushita N, Nakatani H. Primary aspergillosis of the larynx associated with CD4+ T lymphocytopenia. J Laryngol Otol 2002;116:304-6.

92. Yamashita Y, Kumabe T, Jokura H, Tominaga T, Yoshimoto T. Intracranial dissemination from thoracic spinal cord anaplastic astrocytoma in a patient with idiopathic CD4-positive T lymphocytopenia: A case report. Surg Neurol 2001;56:39-41.

93. Cunningham-Rundles C, Murray HW, Smith JP. Treatment of idiopathic CD4 T lymphocytopenia with IL-2. Clin Exp Immunol 1999;116:322-5.

94. Hirasaki S, Koide N, Ogawa H, Tsuji T. Active intestinal tuberculosis with esophageal candidiasis due to idiopathic CD4(+) T-lymphocytopenia in an elderly woman. J Gastroenterol 2000;35:47-51.

95. Ishida T, Hashimoto T, Arita M, Ito I, Osawa M. Pulmonary Mycobacterium avium disease in a young patient with idiopathic CD4+ T lymphocytopenia. Intern Med 1998;37:622-4.

96. Kony SJ, Hane AA, Larouze B, Samb A, Cissoko S, Sow PS, et al. Tuberculosisassociated severe CD4+ T-lymphocytopenia in HIV-seronegative patients from Dakar. SIDAK Research Group. J Infect 2000;41:167-71.

97. Lin JC, Tripathi HM. Pure red cell aplasia and idiopathic CD4 T-lymphocytopenia. Clin Infect Dis 1994;18:651-2.

98. Macon WR, Lo SC, Poiesz BJ, Montefiori DC, Dawson MS, Mason TE, et al. Acquired immunodeficiency syndrome-like illness associated with systemic Mycoplasma fermentans infection in a human immunodeficiency virus-negative homosexual man. Hum Pathol 1993;24:554-8.

99. Plonquet A, Bassez G, Authier FJ, Dray JM, Farcet JP, Gherardi RK. Toxoplasmic myositis as a presenting manifestation of idiopathic CD4 lymphocytopenia. Muscle Nerve 2003;27:761-5.

100. Sternfeld T, Nigg A, Belohradsky BH, Bogner JR. Treatment of relapsing Mycobacterium avium infection with interferon-gamma and interleukin-2 in an HIV-negative patient with low CD4 syndrome. Int J Infect Dis 2010;14(Suppl 3):e198-201.

101. Trojan T, Collins R, Khan DA. Safety and efficacy of treatment using interleukin-2 in a patient with idiopathic CD4(+) lymphopenia and Mycobacterium avium-intracellulare. Clin Exp Immunol 2009;156:440-5.

102. Tsagarakis NJ, Argyrou A, Gortzolidis G, Kentrou N, Papadhimitriou SI, Tzanetou K, et al. Report of an HIV and HHV-8 negative case of primary effusion lymphoma with idiopathic T4 lymphocytopenia. Int J Hematol 2009;90:94-8.

103. Castro A, Pedreira J, Soriano V, Hewlett I, Jhosi B, Epstein J, et al. Kaposi's sarcoma and disseminated tuberculosis in HIV-negative individual. Lancet 1992;339:868.

104. Hayashi T, Hinoda Y, Takahashi T, Adachi M, Miura S, Izumi T, et al. Idiopathic CD4+ T-lymphocytopenia with Bowen's disease. Intern Med 1997;36:822-4.

105. Ho DD, Cao Y, Zhu T, Farthing C, Wang N, Gu G, et al. Idiopathic CD4+ T-lymphocytopenia--immunodeficiency without evidence of HIV infection. N Engl J Med 1993;328:380-5.

106. Inhoff O, Doerries K, Doerries R, Scharf J, Groden C, Goerdt S, et al. Disseminated cutaneous Kaposi sarcoma and progressive multifocal leukoencephalopathy in a patient with idiopathic CD4+ T lymphocytopenia. Arch Dermatol 2007;143:673-5.

107. Iwase T, Ojika K, Katada E, Mitake S, Nakazawa H, Matsukawa N, et al. An unusual course of progressive multifocal leukoencephalopathy in a patient with idiopathic CD4+ T lymphocytopenia. J Neurol Neurosurg Psychiatry 1998;64:788-91. 
108. Manchado Lopez P, Ruiz de Morales JM, Ruiz Gonzalez I, Rodriguez Prieto MA. Cutaneous infections by papillomavirus, herpes zoster and Candida albicans as the only manifestation of idiopathic CD4+ T lymphocytopenia. Int J Dermatol 1999;38:119-21.

109. Ostrowski M, Salit IE, Gold WL, Sutton D, Montpetit ML, Lepine D, et al. Idiopathic CD4+ T-lymphocytopenia in two patients. CMAJ Can Med Assoc J 1993;149:1679-83.

110. Quiles I, Anaut P, Cibrian F, Gainzarain J, Vega L, Andia A. Idiopathic CD4+ T-lymphocytopenia with opportunistic infection and nonHodgkin's lymphoma. J Intern Med 1995;238:183-4.

111. Tassinari P, Deibis L, Bianco N, Echeverria de Perez G. Lymphocyte subset diversity in idiopathic CD4+ T lymphocytopenia. Clin Diagn Lab Immunol 1996;3:611-3.

112. Tsalik EL, Jaggers LB. Life-threatening asymptomatic incidentaloma: a case report of idiopathic CD4 lymphocytopenia and opportunistic infections. Am J Med Sci 2010;340:158-9.

113. Airo P, Caruso A, Stellini R, Antonioli C, Malacarne F, Licenziati S, et al. Characterization of gammadelta T cells expressing CD158b, a killer cell inhibitory receptor, in a patient with chronic $\mathrm{CD} 4(+)$ lymphocytopenia and disseminated Mycobacterium intracellulare infection. Clin Immunol 2000;96:67-75.

114. Centers for Disease C. Unexplained CD4+ T-lymphocyte depletion in persons without evident HIV infection-United States. MMWR Morbidity Mortality Wkly Rep 1992;41:541-5.

115. Lalonde RG, Rene P, Wainberg MA. Opportunistic infections and CD4+ T-lymphocytopenia without HIV infection: report of two cases. Can Med Assoc J CMAJ 1993;149:179-82.

116. Matsuyama W, Tsurukawa T, Iwami F, Wakimoto J, Mizoguchi A, Kawabata M, et al. Two cases of idiopathic CD4+ T-lymphocytopenia in elderly patients. Intern Med 1998;37:891-5.

117. Montella F, Viola P, Recchia O, Di Sora F, Rezza G. CD4+ T-lymphocytopenia and severe infections in an HIV-negative Ethiopian man. AIDS 1994;8:390-1.

118. Neumeister B, Zollner TM, Krieger D, Sterry W, Marre R. Mycetoma due to Exophiala jeanselmei and Mycobacterium chelonae in a 73-year-old man with idiopathic CD4+ T lymphocytopenia. Mycoses 1995;38:271-6.

119. Roger PM, Bernard-Pomier G, Counillon E, Breittmayer JP, Bernard A, Dellamonica P. Overexpression of Fas/CD95 and Fas-induced apoptosis in a patient with idiopathic CD4+ T lymphocytopenia. Clin Infect Dis 1999;28:1012-6.

120. Seligmann M, Autran B, Rabian C, Ferchal F, Olive D, Echard M, et al. Profound and possibly primary "idiopathic CD4+ T lymphocytopenia" in a patient with fungal infections. Clin Immunol Immunopathol 1994;71:203-7.

121. Sinicco A, Maiello A, Raiteri R, Sciandra M, Dassio G, Zamprogna C, et al. Pneumocystis carinii in a patient with pulmonary sarcoidosis and idiopathic CD4+ T lymphocytopenia. Thorax 1996;51:446-7: discussion 8-9.

122. Suzuki Y, Suzuki S, Numata M, Matsumoto Y, Suzuki J, Ikeda H, et al. Acute respiratory failure due to miliary tuberculosis in a patient with idiopathic CD4+ T-lymphocytopaenia. Respirat Med 1998;92:977-9.

123. Chikezie PU, Greenberg AL. Idiopathic CD4+ T lymphocytopenia presenting as progressive multifocal leukoencephalopathy: Case report. Clin Infect Dis 1997;24:526-7.

124. Dalal P, Chernin L, Swender D, Tcheurekdjian H, Hostoffer R. Histoplasmosis in the olecranon bursa of a patient with idiopathic CD4 lymphocytopenia. Ann Allergy Asthma Immunol 2011;107:543-4.

125. Gautier V, Chanez P, Vendrell JP, Pujol JL, Lacoste JY, De Faucal H, et al. Unexplained CD4-positive T-cell deficiency in non-HIV patients presenting as a Pneumocystis carinii pneumonia. Clin Exp Allergy 1991;21:63-6.

126. Gheuens S, Pierone G, Peeters P, Koralnik IJ. Progressive multifocal leukoencephalopathy in individuals with minimal or occult immunosuppression. J Neurol Neurosurg Psychiatry 2010;81:247-54.

127. Goktay F, Mansur AT, Ersahin M, Adaleti R, Gunes P. Idiopathic CD4+
T lymphocytopenia with epidermodysplasia verruciformis-like skin eruption, Nocardia farcinica brain abscesses and pulmonary tuberculosis: A case report with fatal outcome. J Dermatol 2011;38:930-3.

128. Haider S, Nafziger D, Gutierrez JA, Brar I, Mateo N, Fogle J. Progressive multifocal leukoencephalopathy and idiopathic CD4+lymphocytopenia: A case report and review of reported cases. Clin Infect Dis 2000;31:E20-2.

129. Hayashi Y, Kimura A, Kato S, Koumura A, Sakurai T, Tanaka Y, et al. Progressive multifocal leukoencephalopathy and CD4+ T-lymphocytopenia in a patient with Sjogren syndrome. J Neurol Sci 2008;268:195-8.

130. Rueger MA, Miletic H, Dorries K, Wyen C, Eggers C, Deckert M, et al. Long-term remission in progressive multifocal leukoencephalopathy caused by idiopathic CD4+ T lymphocytopenia: A case report. Clin Infect Dis 2006;42:e53-6.

131. Petersen EJ, Rozenberg-Arska M, Dekker AW, Clevers HC, Verdonck LF. Allogeneic bone marrow transplantation can restore CD4+ T-lymphocyte count and immune function in idiopathic CD4+ T-lymphocytopenia. Bone Marrow Transplant 1996;18:813-5.

132. Vargas J, Gamboa C, Negrin D, Correa M, Sandoval C, Aguiar A, et al. Disseminated Mycobacterium mucogenicum infection in a patient with idiopathic CD4 + T lymphocytopenia manifesting as fever of unknown origin. Clin Infect Dis 2005;41:759-60.

133. Cardoso A, Gouveia J, Viegas C, Martins F, Maltez C, Campante F. P0726 idiopathic CD4 lymphocytopenia. EurJ Intern Med 2009;20(Suppl 1):S237.

134. Daus H, Schwarze G, Radtke H. Reduced CD4+ count, infections, and immune thrombocytopenia without hiv infection. Lancet 1989;334:559-60.

135. Davis LJ, Weiler CR. Clinical presentation of five patients with idiopathic CD4+T-lymphocytopenia. J Allergy Clin Immunol 2003;111(1, Supplement 2):S224.

136. Gupta N, Alcid D, Sharma R, Silverman B, Schneider AT. Two patients with idiopathic CD4 (+) T-lymphocytopenia presenting with opportunistic infections. J Allergy Clin Immunol 2006;117(2, Supplement):S172.

137. Hostoffer Jr RW, Eagam M. Idiopathic CD4 Lymphocytopenia with cryptococcal pneumonia: A case report in literature in review. J Allergy Clin Immunol 2007;119(1, Supplement):S94.

138. Manconi PE, Biddau PF, Di Martino ML, Muggianu E, Cau MG, Ibba A, et al. Idiopathic CD4+ T lymphocytopenia with prickle cell carcinoma of the tongue: A case report. Immunol Lett 1997;56:451.

139. Moraes-Vasconcelos D, Chuffi-Barros N, Cordeiro E, Grumach A, Duarte AJ. T.131. disseminated common warts in idiopathic CD4 lymphocytopenia patients: Response to treatment with interferonalpha. Clin Immunol 2009;131(Suppl):S90.

140. Sanchez MR, Guidos G, Huerta JG. Idiopathic Cd4+ lymphocytopenia associated with cryptococcal meningitis in one pediatric patient. J Allergy Clin Immunol 2006;117(Suppl):S169.

141. Schulz C, Zollner TM, Podda M, Kaufmann R. Idiopathic CD4+ T-lymphocytopenia caused by CD28 signaling deficiency. J Dermatol Sci 1998;16(Suppl 1):S197.

142. Soteres DF, El-Dahr JM. Up-regulated apoptosis in the skin of a 15 year old boy with disseminated papillomatosis and idiopathic CD4+ lymphocytopenia. J Allergy Clin Immunol 2005;115(2, Suppl):S227.

143. Hubert P, Seligmann M, Krivitzky A, Debré P, Autran B. Severe idiopathic CD4 lymphocytopenia: Biochemical and functional studies reveal different CD4 T cell defects in two patients. Immunol Lett 1997;56:173.

144. McEldowney SJ, Bush RK. Idiopathic CD4+ Lymphocytopenia in a patient with progressive multifocal leukoencephalopathy treated with cidofovir. J Allergy Clin Immunol 2007;119(Suppl):S253.

145. Fierro MT, Savoia P, Quaglino P, Novero D, Bernengo MG. Disseminated Kaposi's sarcoma associated with idiopathic CD4+ lymphocytopenia and low dose steroid therapy. Clin Exp Dermatol 2005;30:395-7.

146. Lee PI, Ciccone EJ, Read SW, Asher A, Pitts R, Douek DC, et al. Evidence for translocation of microbial products in patients with idiopathic CD4 lymphocytopenia. J Infect Dis 2009;199:1664-70.

147. Kutukculer N, Aksu G, Genel F, Ozturk C. Idiopathic CD4+ T cell 
lymphocytopenia with the absence of B cells and CD8 $+28+$ cells in peripheral blood. Clin Exp Med 2002;2:143-6.

148. Scott-Algara D, Balabanian K, Chakrabarti LA, Mouthon L, Dromer F, Didier C, et al. Idiopathic CD4+ T-cell lymphocytopenia is associated with impaired membrane expression of the chemokine receptor CXCR4. Blood 2010;115:3708-17.

149. Malaspina A, Moir S, Chaitt DG, Rehm CA, Kottilil S, Falloon J, et al. Idiopathic CD4+ $\mathrm{T}$ lymphocytopenia is associated with increases in immature/transitional B cells and serum levels of IL-7. Blood 2007;109:2086-8.

150. DeHovitz JA, Feldman J, Landesman S. Idiopathic CD4+ T-lymphocytopenia. N Engl J Med 1993;329:1045-6.

151. Fantin B, Joly V, Elbim C, Golmard JL, Gougerot-Pocidalo MA, Yeni P, et al. Lymphocyte subset counts during the course of community-acquired pneumonia: evolution according to age, human immunodeficiency virus status, and etiologic microorganisms. Clin Infect Dis 1996;22:1096-8.

152. Blumberg RS, Schooley RT. Lymphocyte markers and infectious diseases. Semin Hematol 1985;22:81-114.

153. Laurence J. T-cell subsets in health, infectious disease, and idiopathic CD4+ T lymphocytopenia. Ann Intern Med 1993;119:55-62.

154. Djomand G, Diaby L, N'Gbichi JM, Coulibaly D, Kadio A, Yapi A, et al. Idiopathic CD4+ T-lymphocyte depletion in a west African population. AIDS 1994;8:843-7.

155. Pilheu JA, De Salvo MC, Gonzalez J, Rey D, Elias MC, Ruppi MC. CD4+ T-lymphocytopenia in severe pulmonary tuberculosis without evidence of human immunodeficiency virus infection. Int J Tubercul Lung Dis 1997;1:422-6.

156. Prince HE, Jensen ER, York J. Lymphocyte subsets in HTLV-II-infected former blood donors: Relationship to spontaneous lymphocyte proliferation. Clin Immunol Immunopathol 1992;65:201-6.

157. Ayoub JP, Palmer JL, Huh Y, Cabanillas F, Younes A. Therapeutic and prognostic implications of peripheral blood lymphopenia in patients with Hodgkin's disease. Leuk Lymph 1999;34:519-27.

158. Henriksson G, Manthorpe R, Bredberg A. Antibodies to CD4 in primary Sjogren's syndrome. Rheumatology 2000;39:142-7.

159. Smolen JS, Chused TM, Leiserson WM, Reeves JP, Alling D, Steinberg AD. Heterogeneity of immunoregulatory T-cell subsets in systemic lupus erythematosus. Correlation with clinical features. Am J Med 1982;72:783-90.

160. Morimoto C, Reinherz EL, Distaso JA, Steinberg AD, Schlossman SF. Relationship between systemic lupus erythematosus $\mathrm{T}$ cell subsets, anti-T cell antibodies, and T cell functions. J Clin Investig 1984;73:689-700.

161. Gluck T, Kiefmann B, Grohmann M, Falk W, Straub RH, Scholmerich J. Immune status and risk for infection in patients receiving chronic immunosuppressive therapy. J Rheumatol 2005;32:1473-80.

Cite this article as: Ahmad DA, Esmadi M, Steinmann WC. Idiopathic CD4 Lymphocytopenia: Spectrum of opportunistic infections, malignancies, and autoimmune diseases. Avicenna J Med 2013;3:37-47.

Source of Support: Nil, Conflict of Interest: None declared.

\section{“QUICK RESPONSE CODE” LINK FOR FULL TEXT ARTICLES}

The journal issue has a unique new feature for reaching to the journal's website without typing a single letter. Each article on its first page has a "Quick Response Code". Using any mobile or other hand-held device with camera and GPRS/other internet source, one can reach to the full text of that particular article on the journal's website. Start a QR-code reading software (see list of free applications from http://tinyurl.com/yzlh2tc) and point the camera to the QR-code printed in the journal. It will automatically take you to the HTML full text of that article. One can also use a desktop or laptop with web camera for similar functionality. See http://tinyurl.com/2bw7fn3 or http://tinyurl.com/3ysr3me for the free applications. 